\title{
Instrumental seismicity of the Amatrice earthquake epicentral area: a review
}

\author{
MARIA GRAZIA CIACCIO * \\ Istituto Nazionale di Geofisica e Vulcanologia \\ *mariagrazia.ciaccio@ingv.it
}

\begin{abstract}
This study presents a preliminary review of the instrumental seismicity of the Norcia-Amatrice area (central Italy) during the years preceding the on-going seismic sequence started on August 24th 2016 with a Mw 6.0 earthquake and occurred close to Accumoli village; a Mw 5.9 happened on October 26th, two months later, $3 \mathrm{~km}$ West of Visso and finally a Mw 6.5 on October $30 \mathrm{th}, 6 \mathrm{~km}$ North of Norcia, the largest earthquake recorded in Italy since the Mw 6.91980 Irpinia event.

The clustering of earthquakes in time and space has been investigated by analysing seismic catalogs for the period 1981-2016, the CMT (Centroid Moment Tensor) catalogue and the TDMT (Time Domain Moment Tensor) solutions.

The seismicity of this region is characterized by different types of activity: single events, minor sequences and swarms with hypocenters within the upper $15 \mathrm{~km}$ of the crust.

A minor sequence on March 2007 (with maximum Mw 3.9 not followed by significant seismicity) affected the area East of Norcia close to the August 24th Mw 5.4 and close to the October 30th Mw 6.5. In the central area, near Accumoli, and in the southern sector close to Amatrice, minor seismic sequences occurred on February 2014 with a Ml 3.5 mainshock and on November 2013 with a Mw3.7 mainshock, respectively. We integrated hypocentral locations and fault plane solutions to give a first look at the main features of the instrumental seismicity compared to the present seismic sequence in order to relate seismicity patterns to the seismogenic structures of the target area.
\end{abstract}

Key words: small magnitude earthquake, seismic sequence, central Apennines

\section{INTRODUCTION}

$\prod$ he study area is located in the seismogenic zone of the central Apennines, an high hazard region, characterised by widespread seismic activity. Figure 1 shows the epicenters of the earthquakes with $\mathrm{M}>5.0$ related to the most important seismic sequences occurred in the target region over the last 35 years and the maximum expected values of peak ground acceleration. These seismic sequences activated a $150 \mathrm{~km}$ long and continuous sector of the chain occurring on SW-dipping normal faults. The seismic sequences of Norcia 1979, Colfiorito 1997, and L'Aquila 2009 occurred at the edges of the seismogenic zones that caused the 2016 seismic sequence; the Amatrice earthquake was not forerun by a standard foreshock sequence differently from the 1997 Colfiorito [Chiaraluce et al., 2003] and the 2009 L'Aquila sequence [Lucente et al., 2010; Valoroso et al., 2013].

The analysis of the background seismicity is based on two different catalogs: the Catalogue of the Italian Seismicity [CSI, Castello et al., 2006; http://csi.rm.ingv.it/] for the period 1981- 2002, and the Bollettino Sismico Italiano of INGV [Bollettino Sismico Italiano doi:10.13127/BOLLETTINO/2016.01, ISIDe working group, version 1.0; Amato and Mele, 2008] for the period 2003-2016. 


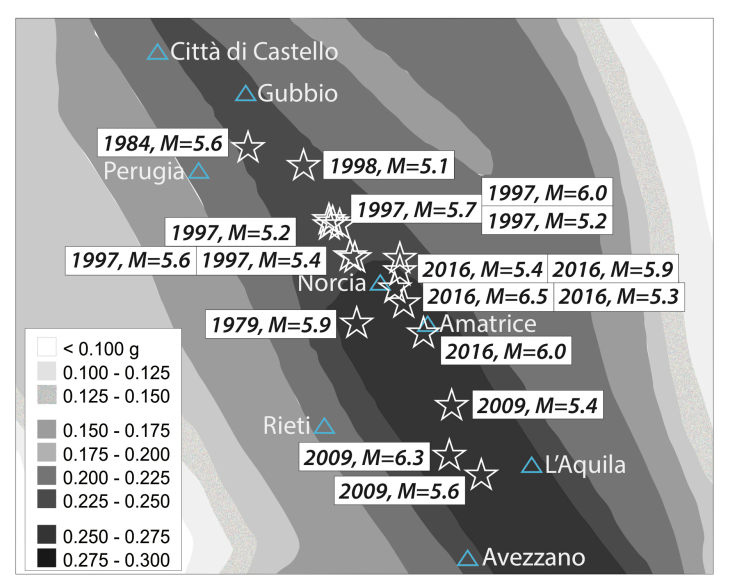

Figure 1. Epicenters of the earthquakes with $M>5.0$ (white stars) related to the most important seismic sequences occurred in the target region over the last 35 years and the maximum expected values of peak ground acceleration. In 2004, it was published the seismic hazard map of Italy (http://zonesismiche.mi.ingv.it) that provides a picture of the most hazardous geographic regions. The seismic hazard map of Italy (GdL MPS, 2004; rif. Ordinanza PCM del 28 aprile 2006, n. 3519, All. 1b) provides the $10 \%$ probability of exceedance in 50 years of the horizontal acceleration at rock sites (i.e., $V s 30>800 \mathrm{~m} / \mathrm{s}$; cat. A, 3.2.1 of the D.M. 14.09.2005) - units of gravity $(g=9.81 \mathrm{~m} / \mathrm{s} 2)$.

More than 8900 earthquakes are available for the selected area. However, the quality of locations, the magnitude completeness (Mc) and the lower magnitude threshold (minimum detection) strongly changed both in space and time, essentially due to the increasing number and improved distribution of seismic stations [Michelini et al., 2016].

The crustal seismicity data shown in Figure 2 represents the instrumental seismicity $(\mathrm{M}>1.5)$ recorded from the 1981 to the 23th August 2016, few hours before the mainshock of the starting of the Amatrice sequence. This seismicity is mainly related to the 1997 Colfiorito seismic sequence to the North, and to the L'Aquila 2009 seismic sequence to the South. Major instrumental earthquakes in this area are related to $\mathrm{W}$-dipping normal faults associated with intramountain basins that represent the surface expression of the extensional strain field. This area of the central Apennines is in fact characterized by a Quaternary extensional regime overprinting NE-verging thrust-sheets [i.e. Vai and Martini, 2001 and references therein] and it was affected by several historical earthquakes (Figure 2, 1627, 1639, 1672, 1703; Rovida et al., 2016).

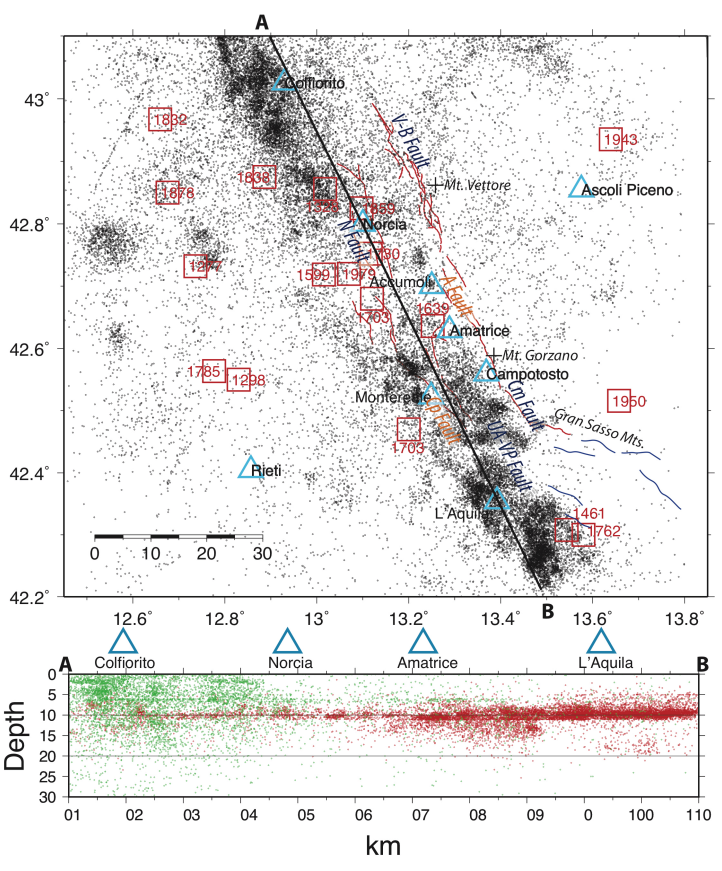

Figure 2. Top: Map showing the distribution of seismicity (1981 - 23th August 2016) in the central Apennines. Squares: historical earthquakes, I>=VIII. Faults: $V-B(M t$ Vettore-Bove) Fault; $N$ (Norcia) Fault; A (Amatrice) Fault; Cm (Campotosto) Fault; Ua-Pa (Upper Aterno-Paganica) Fault; Cp (Capitignano) Fault). Bottom: Vertical section (thickness $15 \mathrm{~km}$ ) of seismicity reported on the Top; Green circles for CSI Catalogue, Red circles for Bulletin catalogue (trace in the upper panel).

The aim of this paper is a preliminary analysis of the space-time distribution of seismicity occurred from 1981 up to 23th August 2016 in the Amatrice-Norcia area, central Italy, as recorded and located in the available earthquakes catalogs CSI, and BSI, the RCMT catalog [Pondrelli et al. 2006] and the TDMT catalog [Scognamiglio et al., 2009]. The distribution of instrumentally recorded earthquakes with magnitude $\mathrm{M}$ 
$>3.5$ (Figure 3, top), compared to the CMTs of the most relevant seismic sequences found in the area, allows to observe that though the studied area was struck by several historical earthquakes, there are few seismic events recorded in the last 35 year with magnitude $\mathrm{M}>4.0$.
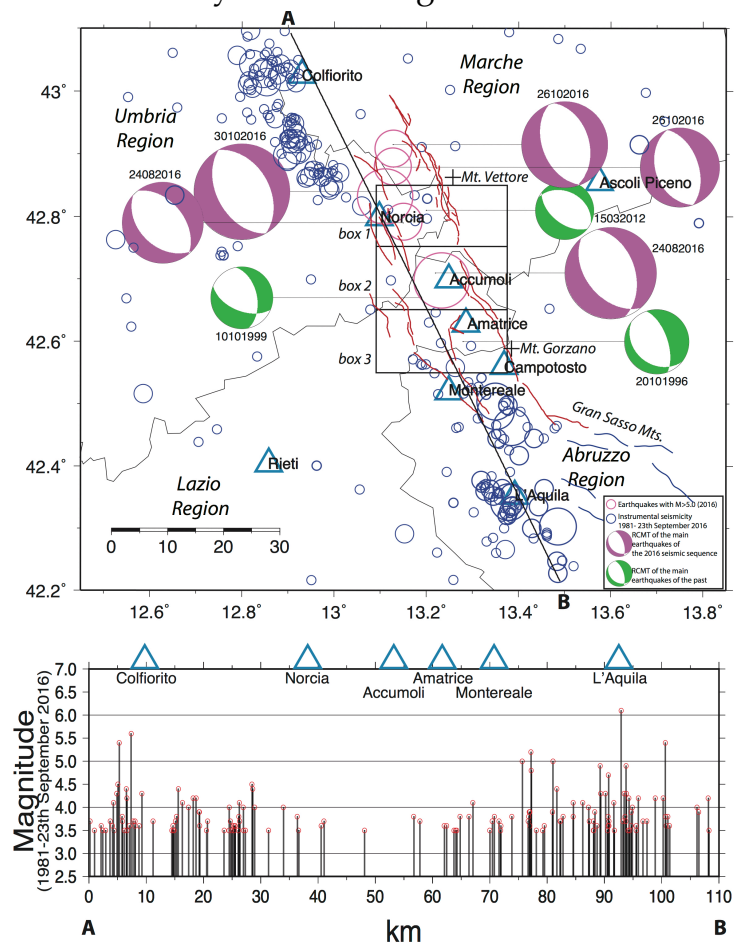

Figure 3. Top: Earthquake fault-plane solutions of major events (CMT solutions) and patterns of seismicity with $M l>=3.5$ in the central Apennines, Italy, from 1981 to the 23th August 2016. CMT solutions for the mainshock and greater aftershock of the Amatrice seismic sequence. Red lines represent the faults mapped by EMERGEO Working Group, 2016. Bottom: the Magnitude of the earthquakes has been projected onto a NW-SE vertical spatial section (15 km thick) along the trend of the Apennines (trace in the upper panel) underlying the lack of strong seismicity in the study area.

\section{SPACE-TIME DisTRIBUTION OF SMALL EARTHQUAKES}

Earthquake catalogs and their content undergo many changes in time due to changes in the seismic networks, data processing techniques, changes in triggering conditions (e.g. number of stations triggered to start location procedures) or attenuation relations. On the basis of the Gutemberg-Richter relationship, the completeness magnitude is $\mathrm{Mc} \cong 1.5$ for the CSI catalogue, and $\mathrm{Mc} \cong 1.8$ for the BSI catalogue [Castello et al., 2006; Moro et al, 2008].

The seismic events with $\mathrm{M} \geq 3.5$ occurred in the area in the past are shown in Figure 3: the observed seismicity recorded in the last decades by the Italian National Seismic Network (RSN) in the area activated by the 24th August 2016 Mw 6.0 mainshock is sparsely distributed in space, with the exception of some minor seismic events. This is confirmed by the distribution of the number of the events versus the Magnitude and versus time, both for the whole area and for the area of the 2016 seismic sequence (Figure 4a, $4 b)$.
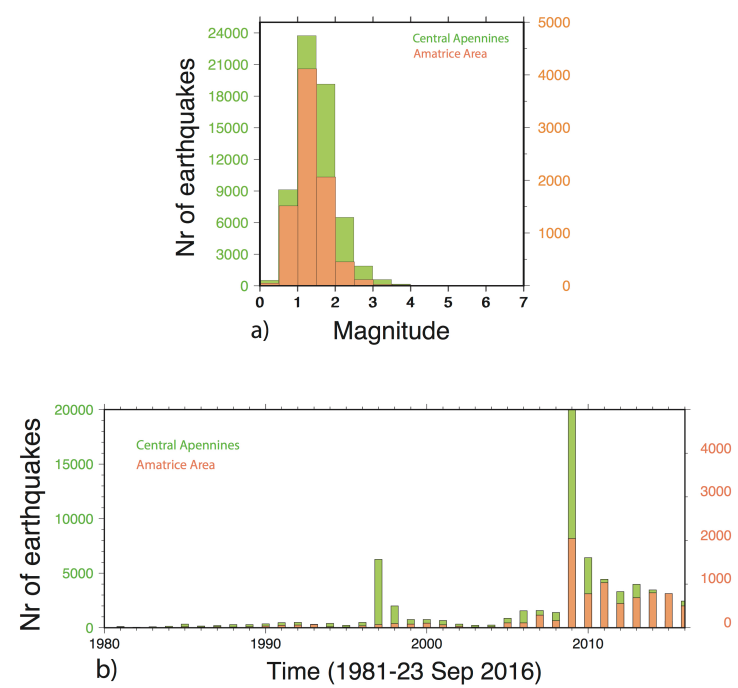

Figure 4. a) Magnitude - earthquake number histogram both for central Apennines (green) than for Amatrice region (orange); b) Time - earthquake number histogram both for central Apennines (green) than for Amatrice region (orange).

Seismicity has also been projected onto a NWSE vertical spatial section along the axis of the Apennines belt (Figure 3, bottom), highlighting the lack of intense seismic activity in the study 
area, the presence of only some earthquake with $\mathrm{M}>3.5$ and identifying the possible mainshocks of the minor seismic sequences activated in the past.

According to such preliminary analysis of the spatial and temporal distribution, the earthquakes in Norcia-Amatrice area can be generally classified into three groups: small-magnitude seismic sequences, earthquake swarm and solitary events.

Small-magnitude seismic sequences are typically characterized by a foreshocks sequence, a mainshock and an aftershocks sequence; an earthquake swarm consists of a group of events where the maximum event does not dominate, which occur in a short time window and within a small hypocentral volume; solitary events are mostly singles, sometimes twins, and they are not accompanied by small events.

In the present work only the first case is discussed, since further more detailed study of clustering is needed to better understand the fault architecture within the fault zone

\section{THE SMALL-MAGNITUDE SEQUENCES}

The Amatrice epicentral area is located between two NNW-SSE-trending regional systems of active normal faults. The western system develops from Colfiorito to Norcia to L'Aquila; the eastern system develops from Mt. Vettore to Amatrice-Campotosto to Gran Sasso Mts. [Boncio et al., 2004a; 2004b]; Calamita and Pizzi, 1992; Cello et al., 1997; Galadini and Galli, 2000; Pizzi and Scisciani, 2000; Lavechia et al., 2002 and references therein].

Earthquakes with $\mathrm{M}>3.5$, and related seismicity, preceding the $2016 \mathrm{Mw} 6.0$ have been identified and analyzed by dividing the target area in three sectors. Earthquake parameters discussed in the text are in Table 1A-D and Table 2.

\section{Box1: Northern Area}

In this area we identify a minor seismic sequence occurred on 29th March 2007 at 04:37 (UTC), when a seismic event of Mw 3.9 hit the zone of Castelluccio Plain (yellow star in Figure 5-BOX1) (Table 1A), an hamlet of Norcia town, close to the August 24th Mw 5.4 and close to the October 30th Mw 6.5, in the plane, at the base of the western Mt. Vettore slope. Here, recent activity of the Mt. Vettore fault affecting a Late Pleistocene-Holocene alluvial fan has been evidenced [Galadini and Galli, 2000).

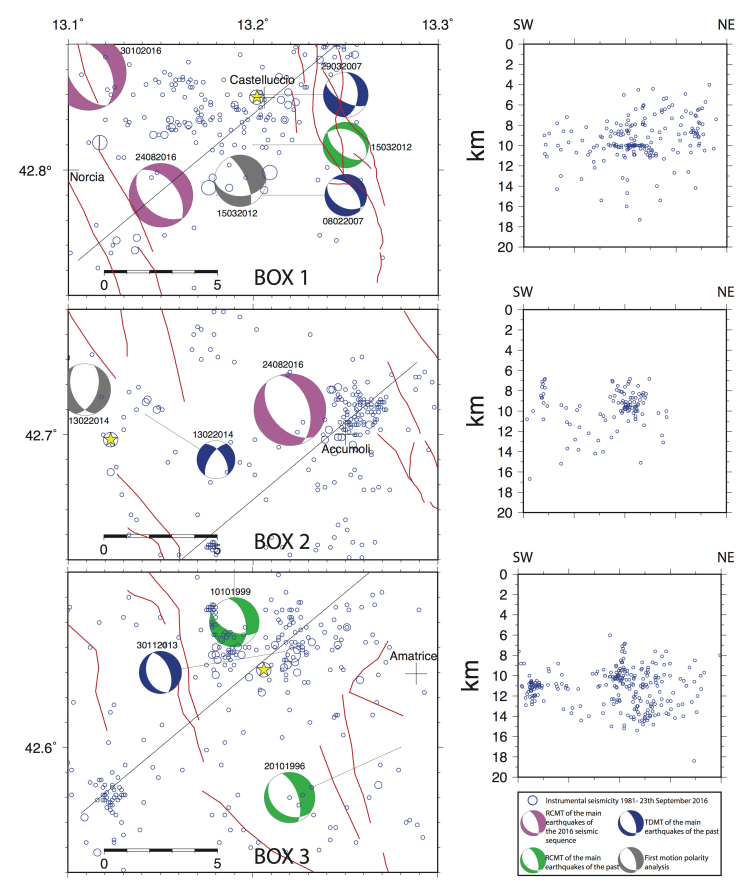

Figure 5. Epicentral map, hypocentral distribution (cross section) and focal mechanisms of the: BOX 1, 2007 Castelluccio seismic sequence, yellow star: February $2007 \mathrm{Mw}$ 3.9 earthquake; BOX2, 2014 Accumoli seismic sequence, yellow star: February 2014 Ml 3.5 earthquake; BOX3, 2013 Amatrice seismic sequence, yellow star: November 2013 Mw 3.7 earthquake.

Earthquakes followed the main event and lasted for more than 8 months, alternating intense activity (March and August) and relative quiescence periods. Such pattern consists of low energy events closely clustered in time and space. About 350 earthquakes $(0.5<=\mathrm{M}<=3.9)$ 
were recorded from February to September 2007 by the RSN; among them, only 5 events had $\mathrm{Md}>=3.0$ (see Table 2). Earthquakes are clustered within an area of $70 \mathrm{~km} 2$ and their hypocentral depths range from 4 to $12 \mathrm{~km}$. The two focal mechanisms available from TDMT catalogue (Table 1C) show a prevalence of normal dip-slip solutions with a strike component.

Moreover, on 15th March 2012 at 03:29 (UTC) a seismic event of Mw 3.7 hit the same zone activated during the 2007 sequence. For this seismic event CMT and TDMT solutions are available, showing a normal faulting mechanism (Figure 3 and Table $1 \mathrm{~B}$ and $1 \mathrm{C}$ for parameters) confirmed by the fault plane solution computed by P-wave first motion reading [FPFIT code, Reasemberg and Oppenheimer, 1985] (Table 1D).

This event was not followed by significant seismicity, pointing out the occurrence of different types of seismicity in a region characterised by a complex system of normal faults such as the central Apennines [Amato and Ciaccio, 2012].

\section{Box2: Central Area}

This is the area where the 24th August 2016 earthquake occurred and it is characterized by the presence, in the past decades, of less seismicity than the surrounding areas. In the catalogues we find only one earthquake with $\mathrm{M}>$ 3.5 occurred on February 2014 Ml 3.5 (yellow star in Figure 5-BOX2; Table 1A).

More than 200 events were identified from February to July 2014, essentially clustered into two confining zones: the first is located $10 \mathrm{~km}$ to the West of the $2016 \mathrm{Mw} 6.0$ mainshock, and the second is above the hypocenter, near the Accumoli village. Hypocentral depths are confined mostly between 7 and $11 \mathrm{~km}$ of depth: in the cross-section the hypocenters delineate approximately a SW-dipping plane ranging from 8 to $14 \mathrm{~km}$ depth and a vertical dipping plane from 7 to $11 \mathrm{~km}$ depth on the western side of the selection. The relationship between this latter cluster of seismicity and the Ml 3.52014 event is not clear (see Figure 5, BOX2). The TDMT solution shows a normal dip slip kinematic, with lateral component (Table 1C) confirmed by the focal mechanism computed by P-wave polarities (Table 1D).

Moreover, on October 1999 a M > 3.5 event occurred in the area with RCMT showing a normal-faulting with strike slip component (Figure 3 ). This event is located in the southern portion of Box 2 with slightly different locations in CSI catalogue and in the RCMT and with large differences in Magnitude value (3.8 and 4.7 respectively) (Table 1A-1B).

\section{Box3: Southern Area}

For this area we have data from catalogs and from literature. This third zone shows the highest seismicity rate in the past with several $\mathrm{M}$ > 3.5 earthquakes. Two seismic events with M3.6 occurred on 10th and 12th August 1981. In Boncio et al. [2004a] three minor sequences have been described occurring on August 1992 (M3.9), June 1994 (M3.7), and October 1996 (M4.0). The 1996 mainshock, in particular, is located at about $12 \mathrm{~km}$ depth and shows a normal dip slip kinematics, with a slight left-lateral component. The minor sequence is clustered at depths between 10 and $14 \mathrm{~km}$ WSW-dipping. The focal mechanisms have a prevailing extensional kinematics, with nearly-horizontal Taxes trending from WSW-ENE to WNW-ESE. Location parameters for the 1996 earthquake are reported in Table 1A and 1B for INGV Bulletin and CMT catalogs.

Moreover, we selected and analyzed the seismic activity started on 2013 (Table 1A and 3A): more than 350 seismic events occurred in this box from October 2013 to May 2014. The strongest earthquake was a Mw 3.7 and occurred on November 30th 2013 (yellow star in Figure 5BOX3): during this day, 22 seismic events occurred with low magnitudes $(M<2.0)$ except 
for one earthquake with $\mathrm{Ml} 3.0$ and three earthquakes with Ml 2.0. This activity has been preceded by more than 100 micro earthquake in the two months before. A swarm of earthquakes with $\mathrm{M}<2.0$ occurred on April-June 2014 in the south-western part of this area. The cross section shows hypocentral depths between 8-15 $\mathrm{km}$, a near vertical aligned for the cluster to the West of the area and no clear alignment for the cluster to the West of Amatrice. The focal mechanism available for the Mw 3.7 shows a normalfaulting mechanism (Table 1C).

\section{CONCLUSIONS}

In this paper we focused on the instrumental seismicity from 1981 to 2016 identifying first order relationships with the recent intense seismic sequence of Amatrice 2016 and active faults of the region.

The seismicity of the central Apennines is characterized by the occurrence of strong earthquakes, as well as by minor sequences and seismic swarms of low energy. Our analysis of space-time distribution of the instrumental seismicity in the Amatrice epicentral area revealed that in the last 35 years, the seismic activity consists of rare $M>4$ events, and few sequences occurred without triggering large events before 2016. The seismicity related to the three small seismic sequences occurred in 2007, 2013 and 2014, refers to a background activity in the depth interval of $4-15 \mathrm{~km}$, with no large mainshocks associated, consisting prevalently of low energy series of events with maximum magnitude M3.9 and spread microseismicity with fluctuations in the seismic energy release rate. Hypocenters of these minor sequences deepen from North to South similarly to what observed for the aftershocks distribution of the 2016 sequence (Michele et al., 2016).

The background seismicity testifies seismic energy release along some of the outermost active normal faults of the central Apennines considered as "silent" [Galadini and Galli, 2000; Falcucci et al., 2016], the Amatrice-Campotosto normal faults and Mt. Vettore normal fault.
For further inferences, a relocation of the identified seismic sequences and a direct comparison with the fault system as revealed by the Amatrice 2016 activation is needed.

\section{AKNOWLEDGMENTS}

I would like to thank Raffaele Di Stefano and Lucia Margheriti for comments that greatly improved the manuscript and the editors for their patience and support.

\section{REFERENCES}

[Amato and Ciaccio, 2012] Amato, A. and Ciaccio, M. G. (2012). Earthquake sequences of the last millennium in L'Aquila and surrounding regions (central Italy). Terra Nova, 24(1), 52-61. [Amato and Mele, 2008] Amato, A. and Mele, F.M. (2008). Performance of the INGV National Seismic Network from 1997 to 2007. Ann. Geophys., 51, 417-431.

[Bollettino Sismico Italiano ] Bollettino Sismico Italiano doi:10.13127/BOLLETTINO/2016.01, ISIDe working group, version 1.0.

[Boncio et al., 2004a] Boncio P., Lavecchia G., Milana G., and Rozzi B. (2004a). Seismogenesis in Central Apennines, Italy: an integrated analysis of minor earthquake sequences and structural data in the Amatrice-Campotosto area. ANNALS OF GEOPHYSICS, VOL. 47, N. 6.

[Boncio et al., 2004b] Boncio, P., Lavecchia, G., and Pace, B. (2004b). Defining a model of 3D seismogenic sources for Seismic Hazard Assessment applications: the case of central Apennines (Italy). Journal of Seismology, 8(3), 407425.

[Calamita and Pizzi, 1992] Calamita, F. and A. Pizzi (1992). Tettonica quaternaria nella dorsale appenninica umbro-marchigiana e bacini intrappenninici associati, Studi Geologici Camerti, 1995/1, 171-182.

[Castello et al., 2006] Castello, B., Selvaggi, G., Chiarabba, C. and Amato, A., (2006). CSI Catalogo Della Sismicita`Italiana 1981-2002, Version 1.1. INGV-CNT, Roma, Available at: 
http://csi.rm.ingv.it/. Last accessed 14/11/2011.

[Cello et al., 1997] Cello, G., S. Mazzoli, E. Tondi and E. Turco (1997). Active tectonics in the central Apennines and possible implications for seismic hazard analysis in peninsular Italy, Tectonophysics, 272, 43-68.

[Chiaraluce et al., 2003] Chiaraluce, L., Ellsworth, W. L., Chiarabba, C., and Cocco, M. (2003). Imaging the complexity of an active normal fault system: The 1997 Colfiorito (central Italy) case study. Journal of Geophysical Research: Solid Earth, 108(B6).

[EMERGEO Working Group, 2016] EMERGEO Working Group (2016). Coseismic effects of the 2016 Amatrice seismic sequence: first geological results. Vol 59, Fast Track 5 (2016): The Amatrice seismic sequence: preliminary data and results.

[Falcucci et al., 2016] Falcucci, E., Gori S., Galadini F., Fubelli G., Moro M., Saroli M. (2016). Active faults in the epicentral and mesoseismal Ml 6.0 24, 2016 Amatrice earthquake region, central Italy. Methodological and seismotectonic issues. Vol 59, Fast Track 5 (2016): The Amatrice seismic sequence: preliminary data and results.

[Galadini and Galli, 2000] Galadini, F. and P. Galli (2000). Active tectonics in the central Apennines (Italy): input data for seismic hazard assessment, Nat. Hazards, 22, 225-270.

[GdL MPS, 2004]

[Lavecchia et al., 2002] Lavecchia, G., Boncio P., Brozzetti F., Stucchi M. and Leschiutta I. (2002). New criteria for seismotectonic zoning in central Italy: insights from the Umbria-Marche Apennines. Boll. Soc. Geol. It., Volume speciale 1, 881-890.

[Lucente et al., 2010] Lucente, F. P. et al. Temporal variation of seismic velocity and anisotropy before the $2009 \mathrm{MW} 6.3$ L'Aquila earthquake, Italy. Geology 38.11 (2010). 10151018. Fast Track 5, 2016; DOI: 10.4401 / ag-7227. [Michele et al., 2016] Michele, M., R. Di Stefano, L. Chiaraluce, M. Cattaneo, P. De Gori, G. Monachesi, D. Latorre, S. Marzorati, L. Valoroso, C.
Ladina, C. Chiarabba, V. Lauciani, M. Fares (2016). Vol 59, Fast Track 5 (2016): The Amatrice seismic sequence: preliminary data and results. [Michelini et al., 2016] Michelini, A., Margheriti, L., Cattaneo, M., Cecere, G., D'Anna, G., Delladio, A., Moretti, M., Pintore, S., Amato, A., Basili, A., Bono, A., Casale, P., Danecek, P., Demartin, M., Faenza, L., Lauciani, V., Mandiello, A. G., Marchetti, A., Marcocci, C., Mazza, S., Mele, F. M., Nardi, A., Nostro, C., Pignone, M., Quintiliani, M., Rao, S., Scognamiglio, L., and Selvaggi G., (2016). The Italian National Seismic Network and the earthquake and tsunami monitoring and surveillance systems. Adv. Geosci., 43, 31-38, doi:10.5194/ adgeo-43-31-2016.

[Moro et al., 2008] Moro, R., Basili A., Bono A., Marcocci C., Mazza S., Mele F. M. (2008). ISIDe, an Italian Seismic Data Base with minimum magnitude of completeness ML 1.8. ESC.

[Pizzi and Scisciani, 2000] Pizzi, A. and V. Scisciani (2000). Methods for determining the Pleistocene-Holocene component of displacement on active faults reactivating pre-Quaternary structures: examples from the central Apennines (Italy), J. Geodyn., 29, 445-457.

[Pizzi and Galadini, 2009] Pizzi, A. and Galadini, F. (2009). Pre-existing cross-structures and active fault segmentation in the northerncentral Apennines (Italy). Tectonophysics, 476(1), 304-319.

[Pondrelli et al., 2006] Pondrelli, S., S. Salimbeni, G. Ekström, A. Morelli, P. Gasperini and G. Vannucci (2006). The Italian CMT dataset from 1977 to the present, Phys. Earth Planet. Int., doi:10.1016/j.pepi.2006.07.008,159/3-4, 286-303.

[Reasemberg and Oppenheimer, 1985] Reasenberg, P.A. and Oppenheimer, D. (1985). FPFIT, FPPLOT and FPPAGE: FORTRAN Computer Programs for Calculating and Displaying Earthquake Fault-Plane Solutions. US Geological Survey Open-File Report 85-739, 109 p.

[Rovida et al., 2016] Rovida A., Locati M., Camassi R., Lolli B., Gasperini P. (eds), (2016). CPTI15, the 2015 version of the Parametric Cat- 
alogue of Italian Earthquakes, Istituto Nazionale di Geofisica e Vulcanologia. doi:http:/ / doi.org/10.6092/ INGV.IT-CPTI15. [Scognamiglio et al., 2009] Scognamiglio L., Tinti E., Michelini A. (2009). Real-Time Determination of Seismic Moment Tensor for the Italian Region. Bulletin of the Seismological Society of America, Vol. 99, No. 4, pp. 2223-2242, August 2009, doi: 10.1785/0120080104.

[Vai and Martini, 2001] Vai, G.B., and L.P. Martini (Ed.), (2001). Anatomy of an orogen: the Apennines and adjacent Mediterranean basins,

\section{TABLES}

Table 1A. Data from INGV Catalogs:

\begin{tabular}{|c|c|c|c|c|}
\hline Date & Lat & Lon & Depth & $M$ \\
\hline $\begin{array}{l}1996- \\
10-20\end{array}$ & 42.550 & 13.250 & 11.9 & $\begin{array}{l}4.1 \\
M l\end{array}$ \\
\hline $\begin{array}{l}1999- \\
10-10\end{array}$ & 42.633 & 13.217 & 4.6 & $\begin{array}{l}3.8 \\
M l\end{array}$ \\
\hline $\begin{array}{l}2007- \\
03-29\end{array}$ & 42.829 & 13.202 & 4.4 & $\begin{array}{l}3.9- \\
M w\end{array}$ \\
\hline $\begin{array}{l}2012- \\
03-15\end{array}$ & 42.797 & 13.201 & 4.3 & $\begin{array}{l}3.7- \\
M w\end{array}$ \\
\hline $\begin{array}{l}2013- \\
11-30\end{array}$ & 42.631 & 13.206 & 10.0 & $\begin{array}{l}3.7- \\
M w\end{array}$ \\
\hline $\begin{array}{l}2014- \\
02-13\end{array}$ & 42.698 & 13.123 & 8.2 & $\begin{array}{l}3.5 \\
M l\end{array}$ \\
\hline
\end{tabular}

Table 1B. Parameters (strike, dip, and rake of the first and second nodal planes) of moment tensor available European - Mediterranean RCMT Catalogue [Pondrelli et al., 2006; http://www.bo.ingv.it/RCMT/]:

\begin{tabular}{lllllll}
\hline Date & \multicolumn{4}{l}{ Strike1 } & \multicolumn{4}{l}{ Strike2 Dip2 } & Mw \\
Depth & \multicolumn{2}{l}{ Dip1 } & Rake1 & \multicolumn{4}{l}{ Rake2 } & & \\
\hline $1996-10-20$ & 128 & 31 & 341 & 63 & - & 4.7 \\
10.0 & -119 & & 74 & & & \\
\hline $1999-10-10$ & 348 & 50 & 112 & 55 & - & 4.7 \\
10.0 & -47 & & 129 & & & \\
\hline $2012-03-15$ & 297 & 36 & 128 & 54 & - & 3.9 \\
6.0 & -99 & & 83 & & & \\
\hline
\end{tabular}

Table 1C. Parameters (strike, dip, and rake of the first and second nodal planes) of TDMT available [Scognamiglio et al., 2009 - http://cnt.rm.ingv.it/tdmt]:
Kluwer Academic Publishers, Dordrecht, The Netherlands, 633 p.

[Valoroso et al., 2013] Valoroso, L., Chiaraluce, L., Piccinini, D., Di Stefano, R., Schaff, D., and Waldhauser, F. (2013). Radiography of a normal fault system by 64,000 high-precision earthquake locations: The 2009 L'Aquila (central Italy) case study. Journal of Geophysical Research: Solid Earth, 118(3), 1156-1176.

\begin{tabular}{|c|c|c|c|}
\hline $\begin{array}{l}\text { Date } \\
\text { Depth }\end{array}$ & $\begin{array}{l}\text { Strike1 } \\
\text { Dip1 Rake1 }\end{array}$ & $\begin{array}{l}\text { Strike2 } \\
\text { Dip2 Rake2 }\end{array}$ & $M w$ \\
\hline $\begin{array}{l}2007-02-08 \\
9.0\end{array}$ & $\begin{array}{lll}318 & 52 & - \\
78 & & \end{array}$ & $11940-105$ & 3.63 \\
\hline $\begin{array}{l}2007-03-29 \\
3.0\end{array}$ & $\begin{array}{l}11964- \\
129\end{array}$ & $146-38$ & 3.88 \\
\hline $\begin{array}{l}2012-03-15 \\
7.0\end{array}$ & $\begin{array}{lll}346 & 85 & -7\end{array}$ & $76 \quad 83-175$ & 3.69 \\
\hline $\begin{array}{l}2013-11-30 \\
7.0\end{array}$ & $\begin{array}{lll}338 & 54 & - \\
92 & & \end{array}$ & $16136 \quad-88$ & 3.67 \\
\hline $\begin{array}{l}2014-02-13 \\
7.0\end{array}$ & $\begin{array}{lll}214 & 62 & - \\
39 & & \end{array}$ & $32556-145$ & 3.31 \\
\hline
\end{tabular}

Table 1D. Parameters (strike, dip, and rake of the first and second nodal planes) of focal mechanisms computed in this study from the P-wave first-motion polarity data:

\begin{tabular}{|c|c|c|c|}
\hline $\begin{array}{l}\text { Date } \\
\text { Depth }\end{array}$ & $\begin{array}{l}\text { Strike1 } \\
\text { Dip1 Rake1 }\end{array}$ & $\begin{array}{l}\text { Strike2 } \\
\text { Dip2 Rake2 }\end{array}$ & $M w$ \\
\hline $\begin{array}{l}2012-03-15 \\
9.1\end{array}$ & $9040-50$ & $33671-54$ & 3.69 \\
\hline $\begin{array}{l}2014-02-13 \\
9.0\end{array}$ & $15848-121$ & $\begin{array}{lll}20 & 50 & -60\end{array}$ & 3.31 \\
\hline
\end{tabular}

Table 2. 2007 Castelluccio data from INGV Catalogs, M>3.0:

\begin{tabular}{lllll}
\hline Date & Lat & Lon & Depth & $M$ \\
\hline $2007-$ & 42.799 & 13.209 & 6.4 & $3.2-$ \\
$02-08$ & & & & $M l$ \\
\hline $2007-$ & 42.775 & 13.018 & 7.3 & $3.4-$ \\
$08-12$ & & & & $M l$ \\
\hline $2007-$ & 42.811 & 13.117 & 8.2 & $3.5-$ \\
$08-16$ & & & & $M l$ \\
\hline $2007-$ & 42.793 & 13.176 & 10.0 & $3.6-$ \\
$02-08$ & & & & $M w$ \\
\hline $2007-$ & 42.829 & 13.202 & 4.4 & $3.9-$ \\
$03-29$ & & & & $M w$ \\
\hline
\end{tabular}

